\title{
THE ABILITY TO USE SUGARS AND SUGAR SUBSTITUTES AS PREBIOTICS BY SERBIAN AUTOCHTHONOUS LACTIC ACID BACTERIA
}

\author{
Mirjana Ž. Grujovič ${ }^{*}$ Katarina G. Mladenović, LJiljana R. Čomić \\ University of Kragujevac, Faculty of Science, Department of Biology and Ecology, \\ Radoja Domanovića 12, 34000 Kragujevac, Serbia \\ *Corresponding author: E-mail: mirjana.grujovic@ pmf.kg.ac.rs
}

(Received December 12, 2020; Accepted April 26, 2020)

\begin{abstract}
The purpose of this study was the investigation of the growth ability of lactic acid bacteria (LAB), isolated from traditionally made cheese from Southeastern Serbia, in the presence of different percent of sugars and sugar substitutes (fructose, lactose, inulin, and mannitol). Dextrose was included for comparative purposes. The results indicated that fructose and lactose stimulated the growth of Lactobacillus strains, with exceptions of Lactobacillus plantarum KGPMF62 and Lb. plantarum LP 299v. Lactose showed similar effects like dextrose on the growth of Lactococcus strains, while higher growth rates of Enterococcus hirae KGPMF9, E. durans KGPMF10, E. faecium KGPMF14, and E. faecalis KGPMF47 were observed for lactose and mannitol. The results indicated the potential use of tested sugars and sugar substitutes as prebiotic compounds for the development of symbiotics with tested LAB, in medical or food industry.
\end{abstract}

Keywords: lactic acid bacteria, sugars, sugar substitutes, prebiotic, probiotic

\section{INTRODUCTION}

The probiotics are defined as feed additives, formed by live microbes that showed a beneficial effect on the host health (SCHREZENMEIR and DE VRESE, 2001). Lactic acid bacteria (LAB) are the most used microorganisms as probiotics because they have "Generally Recognized as Safe" (GRAS) status. Also, they are desirable members of the intestinal microflora (SHOKRYAZDAN et al., 2014). During the last decades, the researchers investigated the Lactobacillus and Lactococcus genera for potential beneficial use for humans as probiotics (KimOto-NIRA et al., 2007; HERNANDEZ-HERNANDEZ et al., 2012; SHOKRYAZDAN et al., 2014). It is noticed the increase of interest regarding the commercial utilization of Lactobacillus strains isolated from traditional and naturally fermented dairy products (MAGDoub et al., 2015). But it is of great importance to mention that the biological effects revealed from probiotics bacteria are strain specific. There is no universal strain that would provide all the suggested benefits, not even strains of the same species (PAVLI et al., 2016). 
The efficiency of added probiotic bacteria depends on dose level, their viability and they must be tolerant to the conditions in the gut environment (ARYANA et al., 2007). To improve these features of probiotic bacteria, fermented food is usually supplemented with prebiotics. Prebiotics has been defined as "nondigestible food components that beneficially affect the host by selectively stimulating the growth and/or activity of one or a limited number of bacteria in the colon, thus improving host health" (ROMANO et al., 2016). They are also defined as "nondigestible food ingredients that beneficially affect the host by selectively stimulating the growth and/or activity bacteria in the colon (probiotics)" (GUSTAW et al., 2011). Glucose and lactose are sugars that are mostly used in glycolysis (fermentation of sugars) by LAB (BINTSIS, 2018). In addition to glucose, there are other hexoses such as fructose, mannose or galactose, which can be consumed by LAB (TAMIME and ROBINSON, 1999). The most famous prebiotic compounds are fructooligosaccharides (FOS) and inulin (BURITI et al., 2007). It is known that FOS and inulin can improve the bioavailability of minerals (such as calcium, magnesium, and iron). They also can increase the activity of beneficial live active cultures and inhibition of harmful bacteria in the digestive tract. Inulin facilitates the digestion of high protein diets, retards fat absorption, provides roughage preventing constipation, remains in digestive tract providing satiety without carrying of extra calories, lowers blood cholesterol and triglycerides, helps with blood glucose control for diabetics and decreases the incidence of colon cancer (ARYANA et al., 2007). KAPLAN and HUTHINS (2000) indicated that the ability of probiotic bacteria to ferment oligosaccharides is an especially important characteristic.

Probiotic cultures for food applications are frequently supplied in dried form, encapsulated, spray-dried, or freeze-dried powders (Ross et al., 2005). So, protective compounds for probiotic cultures are necessary to preclude inactivation during drying and warrant stabilization during storage (ROMANO et al., 2016). There is a great variety of prebiotic compounds; among them, the most studied ones are inulin and FOS. Lipid capsules containing inulin or polydextrose are efficient in protecting Lactobacillus acidophilus exposed to simulated gastric fluids and intestinal fluids (OKURO et al., 2013). The combined use of probiotic strains and prebiotic is encouraged to form symbiotic products in which the prebiotic is an energy source increasing the intestinal survival of the beneficial bacteria.

Due to the considerable scientific and commercial interest in prebiotics and probiotic bacteria as symbiotics, the purpose of this research was to study the capacity of some autochtonous LAB, to ferment lactose, fructose, mannitol and inulin.

\section{MATERIALS AND METHODS}

\section{Microorganisms used in study}

The tested strains were selected from the LAB isolated from three days old Sokobanja cheese (MURUZOVIĆ et al., 2018a; 2018b; GRUJOVIĆ et al., 2019a). The strains being identified to the genus level by physiological and biochemical tests. The chosen strains of LAB were identified as Lactococcus lactis subsp. lactis (one strain), Lc. lactis subsp. lactis biovar. diacetylactis (five strains), Lactobacillus fermentum (two stains), Lb. plantarum (one strain), Lb. brevis (one stain), Enterococcus faecalis (three strains), E. faecium (one strain), E. durans (one strain), and E. hirae (one strain), by using the MALDI-TOF mass spectrometry. The strains were frozen at $-80^{\circ} \mathrm{C}$ in MRS broth with $20 \%$ glycerol. They were subcultured in the same medium at $37^{\circ} \mathrm{C}$ for $16-24 \mathrm{~h}$ before the various assays were performed. 


\section{Determination of the growth of LAB isolates in medium with different type of sugars}

The effect of different types of sugars on the growth of isolated LAB was examined according to the method described in RADA et al. (2008), with some modifications. Bacteria were grown in carbohydrate-free MRS media containing: Pepton Torlak $10.0 \mathrm{~g} / \mathrm{l}$, Meat extract $10.0 \mathrm{~g} / \mathrm{l}$, Yeast extract $5.0 \mathrm{~g} / \mathrm{l}$, Potassium hydrogen phosphate $2.0 \mathrm{~g} / \mathrm{l}$, Sodium chloride $5.0 \mathrm{~g} / \mathrm{l}$, Sodium acetate $2.5 \mathrm{~g} / \mathrm{l}$, Magnesium sulfate $1.1 \mathrm{~g} / \mathrm{l}$, Manganese-sulfate $0.2 \mathrm{~g} / \mathrm{l}$. Lactose, fructose, mannitol, and inulin (individually) (Torlak, Belgrade, Serbia) were added to MRS media. MRS with $2 \%(\mathrm{w} / \mathrm{v})$ of dextrose served as growth control. The inoculum was prepared from $24 \mathrm{~h}$ MRS grown LAB isolates cells and turbidity of initial suspension was adjusted using 0.5 McFarland densitometer (Biosan, Latvia). Initial bacterial suspensions contain about $10^{8}$ colony-forming units $(\mathrm{CFU}) / \mathrm{ml}$. Each bacterial strain $(10 \mu \mathrm{l})$ (individually) was added to the MRS basal media containing different percent of lactose, fructose, mannitol, and inulin. Twofold serial dilutions of the tested sugars were made in sterile tissue culture 96-well microtiter plates (Sarstedt, Germany) containing $0.1 \mathrm{ml}$ of MRS broth (Torlak, Belgrade, Serbia) per well. The tested concentration range was from 8 to $0.25 \%$ (w/v). The incubation was carried out at $37^{\circ} \mathrm{C} / 24 \mathrm{~h}$. Optical densities (ODs) of stained adherent bacteria were determined with an ELISA plate reader (RT-2100C, Rayto, Shenzhen, China) at $600 \mathrm{~nm}$. According to MURUZOVIĆ et al. (2018a), Lb. fermentum KGPMF28, Lb. fermentum KGPMF29, Lb. brevis KGPMF35 and all Lactococcus isolates had no ability to ferment mannitol and inulin, so the growth in these two sugars was not investigated for mentioned isolates.

Only broth or broth with sugars served as a control to check sterility and nonspecific binding of media. To compensate for background absorbance, OD readings from sterile medium and prebiotics extracts were averaged and subtracted from all test values. All tests were performed in triplicate.

\section{Statistical analysis}

All data for measuring the growth of bacteria in the presence of different sugars were presented as means \pm standard deviations using Microsoft Excel (Redmond, Washington, DC, USA). Statistics 20. ANOVA analysis (SPSS Inc., Chicago, IL, USA) was carried out to determine statistical differences $(p<0.05)$ between the growth of bacteria in sugars, compared with growth control ( $2 \%$ of dextrose). The strains were tested three times for each concentration of tested sugars.

\section{RESULTS AND DISCUSSION}

\section{The effect of different type of sugars on the growth of LAB isolates}

The ability of LAB, isolated from the cheese from Southeastern Serbia, to grow in the presence of different sugars (fructose, lactose, and inulin) and sugar alcohol (mannitol) was evaluated. Dextrose was also included in this study for comparative purposes. Results are shown in Tables 1, 2, and 3.

Higher growth rates of all tested Lactobacillus cells were observed for fructose and lactose. The exceptions were Lb. plantarum KGPMF62 and Lb. plantarum LP 299v, which had better growth in the presence of fructose than in inulin (Table 1). 
Lactose showed similar effects like dextrose, except for L. lactis subsp. lactis KGPMF23, which growth was stimulated in lower tested concentrations. Growth in the presence of fructose was limited, compared to growth in dextrose (Table 2).

Higher growth rates of E. hirae KGPMF9, E. durans KGPMF10, E. faecium KGPMF14, and E. faecalis KGPMF47 were observed for lactose and mannitol. The growth in dextrose was significantly higher $(p<0.05)$ compared to growth in fructose.

In general, tested isolates of LABs showed better growth in the presence of lactose compared with other tested sugars. Tested Lactobacillus and Enterococcus isolates showed better growth in the presence of mannitol than in fructose.

Table 1. Growth of Lactobacillus spp. isolates in presence of sugars.

\begin{tabular}{|c|c|c|c|c|c|c|}
\hline \multirow{3}{*}{ Sugar } & \multirow{3}{*}{$\begin{array}{l}\text { Species } \\
\text { Isolate } \\
\text { Percent } \\
(\%)\end{array}$} & \multicolumn{2}{|c|}{ Lb. fermentum } & \multirow{3}{*}{$\begin{array}{l}\text { Lb. brevis } \\
\text { KGPMF35 }\end{array}$} & \multicolumn{2}{|c|}{ Lb.plantarum } \\
\hline & & \multirow[t]{2}{*}{ KGPMF28 } & \multirow[t]{2}{*}{ KGPMF29 } & & \multirow[t]{2}{*}{ KGPMF62 } & \multirow[t]{2}{*}{ LP 299v } \\
\hline & & & & & & \\
\hline Dextrose $^{1}$ & 2 & $0.94 \pm 0.06$ & $0.94 \pm 0.04$ & $0.61 \pm 0.09$ & $0.95 \pm 0.04$ & $0.31 \pm 0.03$ \\
\hline \multirow[t]{6}{*}{ Fructose } & 8 & $0.51 \pm 0.08^{*}$ & $0.52 \pm 0.03^{*}$ & $0.53 \pm 0.00^{*}$ & $0.06 \pm 0.07^{*}$ & $0.14 \pm 0.02^{*}$ \\
\hline & 4 & $0.82 \pm 0.03^{*}$ & $0.96 \pm 0.01$ & $0.60 \pm 0.01$ & $0.72 \pm 0.02^{*}$ & $0.20 \pm 0.02^{*}$ \\
\hline & 2 & $0.90 \pm 0.02$ & $0.98 \pm 0.00^{*}$ & $0.61 \pm 0.00$ & $0.96 \pm 0.01$ & $0.21 \pm 0.01^{*}$ \\
\hline & 1 & $0.92 \pm 0.01$ & $0.99 \pm 0.02^{*}$ & $0.62 \pm 0.04$ & $1.03 \pm 0.04^{*}$ & $0.34 \pm 0.01$ \\
\hline & 0.5 & $0.96 \pm 0.03$ & $1.00 \pm 0.00^{*}$ & $0.68 \pm 0.03^{*}$ & $1.00 \pm 0.02^{*}$ & $0.31 \pm 0.02$ \\
\hline & 0.25 & $0.94 \pm 0.00$ & $0.92 \pm 0.01$ & $0.48 \pm 0.01^{*}$ & $0.51 \pm 0.02^{*}$ & $0.24 \pm 0.01^{*}$ \\
\hline \multirow[t]{6}{*}{ Lactose } & 8 & $0.56 \pm 0.02^{*}$ & $0.53 \pm 0.04^{*}$ & $0.02 \pm 0.06^{*}$ & $0.05 \pm 0.06^{*}$ & $0.15 \pm 0.01^{*}$ \\
\hline & 4 & $0.81 \pm 0.00^{*}$ & $0.74 \pm 0.01^{*}$ & $0.12 \pm 0.00^{*}$ & $0.77 \pm 0.04^{*}$ & $0.19 \pm 0.02^{*}$ \\
\hline & 2 & $0.90 \pm 0.02$ & $0.82 \pm 0.01^{*}$ & $0.25 \pm 0.02^{*}$ & $0.94 \pm 0.02$ & $0.20 \pm 0.02^{*}$ \\
\hline & 1 & $0.91 \pm 0.01$ & $0.88 \pm 0.03^{*}$ & $0.32 \pm 0.00^{*}$ & $1.02 \pm 0.03^{*}$ & $0.31 \pm 0.02$ \\
\hline & 0.5 & $0.94 \pm 0.03$ & $1.01 \pm 0.01^{*}$ & $0.58 \pm 0.04$ & $0.96 \pm 0.03$ & $0.24 \pm 0.00^{*}$ \\
\hline & 0.25 & $0.92 \pm 0.00$ & $0.86 \pm 0.02^{*}$ & $0.41 \pm 0.00^{*}$ & $0.44 \pm 0.04^{*}$ & $0.23 \pm 0.00^{*}$ \\
\hline \multirow[t]{6}{*}{ Mannitol } & 8 & n.d. & n.d. & n.d. & $0.09 \pm 0.09^{*}$ & $0.21 \pm 0.00^{*}$ \\
\hline & 4 & n.d. & n.d. & n.d. & $0.87 \pm 0.02^{*}$ & $0.28 \pm 0.01$ \\
\hline & 2 & n.d. & n.d. & n.d. & $0.96 \pm 0.01$ & $0.30 \pm 0.02$ \\
\hline & 1 & n.d. & n.d. & n.d. & $0.97 \pm 0.03$ & $0.26 \pm 0.01^{*}$ \\
\hline & 0.5 & n.d. & n.d. & n.d. & $0.94 \pm 0.01$ & $0.19 \pm 0.03^{*}$ \\
\hline & 0.25 & n.d. & n.d. & n.d. & $0.44 \pm 0.03^{*}$ & $0.17 \pm 0.01^{*}$ \\
\hline \multirow[t]{6}{*}{ Inulin } & 8 & n.d. & n.d. & n.d. & $0.60 \pm 0.05^{*}$ & $0.18 \pm 0.01^{*}$ \\
\hline & 4 & n.d. & n.d. & n.d. & $0.68 \pm 0.01^{*}$ & $0.20 \pm 0.01^{*}$ \\
\hline & 2 & n.d. & n.d. & n.d. & $0.88 \pm 0.01^{*}$ & $0.23 \pm 0.00^{*}$ \\
\hline & 1 & n.d. & n.d. & n.d. & $0.79 \pm 0.00^{*}$ & $0.22 \pm 0.00^{*}$ \\
\hline & 0.5 & n.d. & n.d. & n.d. & $0.47 \pm 0.00^{*}$ & $0.21 \pm 0.01^{*}$ \\
\hline & 0.25 & n.d. & n.d. & n.d. & $0.38 \pm 0.03^{*}$ & $0.19 \pm 0.01^{*}$ \\
\hline
\end{tabular}

Values are presented as mean \pm SD measured at $600 \mathrm{~nm}$; ${ }^{1}$ growth control; n.d.-not determined (isolates did not ferment mannitol and inulin); ${ }^{*}$ statistical significance $(p<0.05)$ in the growth of bacteria compared with growth control ( $2 \%$ of dextrose). 
Table 2. Growth of Lactococcus spp. isolates in presence of sugars.

\begin{tabular}{|c|c|c|c|c|c|c|c|}
\hline \multirow{3}{*}{ Sugar } & \multirow{2}{*}{$\begin{array}{r}\text { Species } \\
\text { Isolate }\end{array}$} & \multirow{2}{*}{$\begin{array}{c}\text { L. lactis subsp. lactis } \\
\text { KGPMF23 }\end{array}$} & \multicolumn{5}{|c|}{ L. lactis subsp. lactis biovar. diacetylactis } \\
\hline & & & \multirow[t]{2}{*}{ KGPMF50 } & \multirow[t]{2}{*}{ KGPMF54 } & \multirow[t]{2}{*}{ KGPMF55 } & \multirow[t]{2}{*}{ KGPMF57 } & \multirow[t]{2}{*}{ KGPMF59 } \\
\hline & $\begin{array}{l}\text { Percent of } \\
\text { sugar }(\%)\end{array}$ & & & & & & \\
\hline Dextrose $^{1}$ & 2 & $0.64 \pm 0.03$ & $0.34 \pm 0.08$ & $0.52 \pm 0.02$ & $0.36 \pm 0.05$ & $0.93 \pm 0.02$ & $0.81 \pm 0.06$ \\
\hline \multirow[t]{6}{*}{ Fructose } & 8 & $0.17 \pm 0.02^{*}$ & $0.15 \pm 0.01^{*}$ & $0.16 \pm 0.02^{*}$ & $0.18 \pm 0.00^{*}$ & $0.52 \pm 0.04^{*}$ & $0.40 \pm 0.02^{*}$ \\
\hline & 4 & $0.19 \pm 0.02^{*}$ & $0.17 \pm 0.03^{*}$ & $0.34 \pm 0.02^{*}$ & $0.19 \pm 0.02^{*}$ & $0.73 \pm 0.02^{*}$ & $0.64 \pm 0.00^{*}$ \\
\hline & 2 & $0.20 \pm 0.03^{*}$ & $0.20 \pm 0.02^{*}$ & $0.42 \pm 0.01^{*}$ & $0.22 \pm 0.01^{*}$ & $0.79 \pm 0.00^{*}$ & $0.66 \pm 0.00^{*}$ \\
\hline & 1 & $0.30 \pm 0.01^{*}$ & $0.27 \pm 0.02^{*}$ & $0.46 \pm 0.02^{*}$ & $0.27 \pm 0.00^{*}$ & $0.84 \pm 0.03^{*}$ & $0.67 \pm 0.01^{*}$ \\
\hline & 0.5 & $0.25 \pm 0.02^{*}$ & $0.22 \pm 0.04^{*}$ & $0.48 \pm 0.00$ & $0.33 \pm 0.03$ & $0.82 \pm 0.01^{*}$ & $0.66 \pm 0.00^{*}$ \\
\hline & 0.25 & $0.21 \pm 0.01^{*}$ & $0.22 \pm 0.01^{*}$ & $0.45 \pm 0.01^{*}$ & $0.31 \pm 0.02^{*}$ & $0.81 \pm 0.00^{*}$ & $0.64 \pm 0.00^{*}$ \\
\hline \multirow[t]{6}{*}{ Lactose } & 8 & $0.08 \pm 0.04^{*}$ & $0.31 \pm 0.04$ & $0.31 \pm 0.02^{*}$ & $0.23 \pm 0.00^{*}$ & $0.60 \pm 0.04^{*}$ & $0.40 \pm 0.02^{*}$ \\
\hline & 4 & $0.11 \pm 0.02^{*}$ & $0.18 \pm 0.03^{*}$ & $0.33 \pm 0.01^{*}$ & $0.25 \pm 0.01^{*}$ & $0.79 \pm 0.03^{*}$ & $0.58 \pm 0.02^{*}$ \\
\hline & 2 & $0.26 \pm 0.01^{*}$ & $0.15 \pm 0.04^{*}$ & $0.35 \pm 0.02^{*}$ & $0.27 \pm 0.02^{*}$ & $0.86 \pm 0.04^{*}$ & $0.63 \pm 0.01^{*}$ \\
\hline & 1 & $0.65 \pm 0.01$ & $0.10 \pm 0.01^{*}$ & $0.44 \pm 0.02^{*}$ & $0.36 \pm 0.01$ & $0.90 \pm 0.04$ & $0.69 \pm 0.02^{*}$ \\
\hline & 0.5 & $0.64 \pm 0.00$ & $0.09 \pm 0.00^{*}$ & $0.42 \pm 0.00^{*}$ & $0.32 \pm 0.00$ & $0.89 \pm 0.02$ & $0.63 \pm 0.00^{*}$ \\
\hline & 0.25 & $0.52 \pm 0.02^{*}$ & $0.09 \pm 0.01^{*}$ & $0.41 \pm 0.01^{*}$ & $0.30 \pm 0.00^{*}$ & $0.88 \pm 0.01^{*}$ & $0.60 \pm 0.00^{*}$ \\
\hline
\end{tabular}

Values are presented as mean $\pm \mathrm{SD}$ measured at $600 \mathrm{~nm}$; ${ }^{1}$ growth control; * statistical significance $(p<0.05)$ in the growth of bacteria compared with growth control ( $2 \%$ of dextrose). 
Table 3. Growth of Enterococcus spp. isolates in presence of sugars

\begin{tabular}{|c|c|c|c|c|c|c|c|c|}
\hline \multirow{3}{*}{ Sugar } & \multirow{3}{*}{$\begin{array}{r}\text { Species } \\
\text { Isolate } \\
\text { Percent of } \\
\text { sugar }(\%)\end{array}$} & \multirow{3}{*}{$\begin{array}{c}\text { E. hirae } \\
\text { KGPMF9 }\end{array}$} & \multirow{3}{*}{$\begin{array}{c}\text { E. durans } \\
\text { KGPMF10 }\end{array}$} & \multirow{3}{*}{$\begin{array}{l}\text { E. faecium } \\
\text { KGPMF14 }\end{array}$} & \multicolumn{4}{|c|}{ E.faecalis } \\
\hline & & & & & KGPMF47 & KGPMF48 & KGPMF49 & ATCC 29211 \\
\hline & & & & & & & & \\
\hline Dextrose $^{1}$ & 2 & $0.20 \pm 0.02$ & $0.23 \pm 0.08$ & $0.28 \pm 0.02$ & $0.27 \pm 0.04$ & $0.21 \pm 0.02$ & $0.28 \pm 0.03$ & $0.29 \pm 0.03$ \\
\hline \multirow{6}{*}{ Fructose } & 8 & $0.08 \pm 0.05^{*}$ & $0.16 \pm 0.00^{*}$ & $0.19 \pm 0.01^{*}$ & $0.18 \pm 0.01^{*}$ & $0.05 \pm 0.06^{*}$ & $0.21 \pm 0.04^{*}$ & $0.13 \pm 0.02^{*}$ \\
\hline & 4 & $0.15 \pm 0.01^{*}$ & $0.18 \pm 0.01^{*}$ & $0.21 \pm 0.01^{*}$ & $0.23 \pm 0.01^{*}$ & $0.12 \pm 0.02^{*}$ & $0.21 \pm 0.02^{*}$ & $0.16 \pm 0.02^{*}$ \\
\hline & 2 & $0.16 \pm 0.02^{*}$ & $0.17 \pm 0.02^{*}$ & $0.25 \pm 0.00$ & $0.25 \pm 0.02$ & $0.13 \pm 0.02^{*}$ & $0.19 \pm 0.02^{*}$ & $0.18 \pm 0.01^{*}$ \\
\hline & 1 & $0.15 \pm 0.00^{*}$ & $0.24 \pm 0.00$ & $0.26 \pm 0.00$ & $0.25 \pm 0.03$ & $0.13 \pm 0.01^{*}$ & $0.19 \pm 0.02^{*}$ & $0.20 \pm 0.03^{*}$ \\
\hline & 0.5 & $0.19 \pm 0.00$ & $0.21 \pm 0.03$ & $0.28 \pm 0.02$ & $0.26 \pm 0.02$ & $0.17 \pm 0.02^{*}$ & $0.19 \pm 0.00^{*}$ & $0.17 \pm 0.00^{*}$ \\
\hline & 0.25 & $0.17 \pm 0$ & $0.20 \pm 0.02$ & $0.25 \pm 0.01$ & $0.24 \pm 0.03$ & $0.13 \pm 0.03^{*}$ & $0.13 \pm 0.02^{*}$ & $0.11 \pm 0.01^{*}$ \\
\hline \multirow[t]{6}{*}{ Lactose } & 8 & & $0.18 \pm 0.01^{*}$ & $0.22 \pm 0.00^{*}$ & $0.22 \pm 0.00^{*}$ & $0.13 \pm 0.01^{*}$ & $0.22 \pm 0.00^{*}$ & $0.17 \pm 0.00^{*}$ \\
\hline & 4 & $0.18 \pm 0.00$ & $0.18 \pm 0.03^{*}$ & $0.24 \pm 0.02^{*}$ & $0.24 \pm 0.00^{*}$ & $0.10 \pm 0.02^{*}$ & $0.19 \pm 0.01^{*}$ & $0.19 \pm 0.00^{*}$ \\
\hline & 2 & $0.20 \pm 0.01$ & $0.20 \pm 0.03$ & $0.26 \pm 0.01$ & $0.26 \pm 0.01$ & $0.12 \pm 0.00^{*}$ & $0.19 \pm 0.00^{*}$ & $0.21 \pm 0.01^{*}$ \\
\hline & 1 & $0.16 \pm 0.01^{*}$ & $0.24 \pm 0.03$ & $0.29 \pm 0.00$ & $0.27 \pm 0.02$ & $0.11 \pm 0.00^{*}$ & $0.17 \pm 0.00^{*}$ & $0.23 \pm 0.02^{*}$ \\
\hline & 0.5 & $0.16 \pm 0.00^{*}$ & $0.25 \pm 0.01$ & $0.28 \pm 0.00$ & $0.29 \pm 0.00$ & $0.12 \pm 0.00^{*}$ & $0.14 \pm 0.02^{*}$ & $0.18 \pm 0.00^{*}$ \\
\hline & 0.25 & $0.14 \pm 0.00^{*}$ & $0.16 \pm 0.01^{*}$ & $0.27 \pm 0.00$ & $0.27 \pm 0.01$ & $0.11 \pm 0.01^{*}$ & $0.11 \pm 0.01^{*}$ & $0.13 \pm 0.01^{*}$ \\
\hline \multirow[t]{6}{*}{ Mannitol } & 8 & $0.23 \pm 0.02$ & $0.19 \pm 0.03^{*}$ & $0.22 \pm 0.02^{*}$ & $0.23 \pm 0.00^{*}$ & $0.19 \pm 0.03$ & $0.20 \pm 0.03^{*}$ & $0.19 \pm 0.02^{*}$ \\
\hline & 4 & $0.18 \pm 0.02$ & $0.22 \pm 0.01$ & $0.23 \pm 0.02^{*}$ & $0.26 \pm 0.02$ & $0.17 \pm 0.02^{*}$ & $0.23 \pm 0.03^{*}$ & $0.21 \pm 0.02^{*}$ \\
\hline & 2 & $0.15 \pm 0.01^{*}$ & $0.23 \pm 0.03$ & $0.22 \pm 0.01^{*}$ & $0.27 \pm 0.00$ & $0.15 \pm 0.01^{*}$ & $0.23 \pm 0.01^{*}$ & $0.25 \pm 0.01$ \\
\hline & 1 & $0.15 \pm 0.00^{*}$ & $0.27 \pm 0.02^{*}$ & $0.21 \pm 0.00^{*}$ & $0.29 \pm 0.03$ & $0.15 \pm 0.00^{*}$ & $0.24 \pm 0.01^{*}$ & $0.19 \pm 0.01^{*}$ \\
\hline & 0.5 & $0.13 \pm 0.01^{*}$ & $0.24 \pm 0.00$ & $0.21 \pm 0.00^{*}$ & $0.27 \pm 0.01$ & $0.13 \pm 0.00^{*}$ & $0.23 \pm 0.00^{*}$ & $0.16 \pm 0.01^{*}$ \\
\hline & 0.25 & $0.11 \pm 0.02^{*}$ & $0.21 \pm 0.00$ & $0.17 \pm 0.01^{*}$ & $0.24 \pm 0.00$ & $0.13 \pm 0.01^{*}$ & $0.21 \pm 0.00^{*}$ & $0.11 \pm 0.02^{*}$ \\
\hline
\end{tabular}

Values are presented as mean $\pm \mathrm{SD}$ measured at $600 \mathrm{~nm}$; ${ }^{1}$ growth control; "statistical significance $(p<0.05)$ in the growth of bacteria compared with growth control ( $2 \%$ of dextrose). 
LABs from natural food sources can be promising probiotic candidates, which was confirmed in results presented in GRUJOVIĆ et al. (2019b). Therefore, in this paper, for the first time, it was evaluated the symbiotic effect between different types of sugars and sugar substitutes and selected LABs, isolated from traditionally made cheese, in order to determine the possible prebiotic for the growth of tested bacteria. It is well-known that symbiotic is a combination of probiotics and prebiotics and that symbiotic can beneficially affect the host by improving the survival and implantation of live microbial dietary supplements in the gastrointestinal tract (SARANGI et al., 2016). GUSTAW et al. (2011) indicated that fructooligosaccharides and inulin caused an increase in the numbers of all bacteria, in comparison to control yogurt obtained without the addition of prebiotics.

In this paper, it was investigated the ability of some lactobacilli to ferment fructose and dextrose, as well as their ability to ferment inulin. But differences in growth absorbances in inulin, and fructose, and dextrose (individually) were not significant ( $p>$ 0.05). It can be concluded that the ability of an organism to use a polysaccharide depends primarily on its ability to degrade the type of chemical bonds present in the molecule rather than the monomer itself. DA SILVA SABO et al. (2015) indicated that Lb. plantarum ST16 Pa, which grew in $1 \%$ inulin cultures, produced lactic acid at a level that was $36.5 \%$ higher than in the absence of the polysaccharide. But the growth of Lb. plantarum ST16 $\mathrm{Pa}$ in medium without inulin, was 54\% higher, which was confirmed in our work. Also, ALMSTÅHL et al. (2013) indicated that Lactobacillus strains had the ability to ferment, not only sugars but also the sugar substitutes like mannitol, which was also confirmed in our paper for some isolates.

Mannitol, a naturally occurring polyol (sugar alcohol), is widely used in the food, pharmaceutical, medical, and chemical industries. The production of mannitol by fermentation has become attractive because of the problems associated with its production chemically. Several homo- and heterofermentative (LAB) are known to produce mannitol. A several heterofermentative LAB are excellent producers of mannitol from fructose. These bacteria convert fructose to mannitol with $100 \%$ yields from a mixture of glucose and fructose (1:2). Glucose is converted to lactic acid and acetic acid, and fructose is converted to mannitol (SAHA and RACINE, 2011). In our study, tested Lactobacillus and Enterococcus isolates showed better growth in the presence of mannitol, than fructose. According to UROIĆ et al. (2014), L. lactis BGAL1-1 showed no ability to utilize mannitol, which is in accordance with our study. Most of the researches are focused on the influence of these sugars on the growth of bifidobacteria and lactobacilli, but little is known about how they affected on other beneficial bacteria from other genera, like Lactococcus spp., which are widely used in the food industry (PRANCKUTE et al., 2014).

CHEN et al. (2007) investigated the growth of E. faecium MR006 in broths with different sugars and showed that the highest cell numbers were observed with dextrose, which is in accordance with our research. UROIĆ et al. (2014) showed that enterococci isolated from white pickled cheese growth better in MRS broth with mannitol, as prebiotic substrate, which also was in accordance with our research.

\section{CONCLUSION}

The tested LABs, isolated from Sokobanja's cheese, previously showed potential for application as probiotic. In this paper, it was demonstrated their growth ability in the presence of different concentrations of different sugars and sugar substitutes, which can be used as prebiotics. Therefore, this paper contributes to a better knowledge about the 
potential development of symbiotic. Further studies need to include in vivo clinical research and to evaluate the healthy aspect.

\section{Acknowledgments}

This investigation was supported by the Ministry of Education, Science and Technological Development of the Republic of Serbia (Agreement No. 451-032824/2019-14/2).

\section{References:}

[1] AlmstÅHl, A., LingströM, P., Eliasson, L., CARlÉN, A. (2013): Fermentation of sugars and sugar alcohols by plaque Lactobacillus strains. Clinical Oral Investigation 17 (6): 1465-1470. doi: 10.1007/s00784-012-0832-Z

[2] Aryana, K.J., Plauche, S., Rao, R.M., Mc Grew, P., Shah, N.P. (2007): Fat-free plain yogurt manufactured with inulins of various chain lengths and Lactobacillus acidophilus. Journal of Food Science 72 (3): M79-M84. doi: 10.1111/j.1750-3841.2007.00302.x

[4] BINTSIS, T. (2018): Lactic acid bacteria as starter cultures: An update in their metabolism and genetics. AIMS Microbiology 4 (4): 665-684.

doi: 10.3934/microbiol.2018.4.665

[5] Buriti, F.C.A., CARdarelli, H.R., FilisetTi, T.M.C.C., SAAD, S.M.I. (2007): Symbiotic potential of fresh cream cheese supplemented with inulin and Lactobacillus paracasei inco-culture with Streptococcus termophillus. Food Chemistry 104 (4): 1605-1610. doi: 10.1016/j.foodchem.2007.03.001

[6] Chen, Y.S., Srionnual, S., Onda, T., Yanagida, F. (2007): Effects of prebiotic oligosaccharides and trehalose on growth and production of bacteriocins by lactic acid bacteria. Letters in Applied Microbiology 45 (2): 190-193. doi: 10.1111/j.1472765X.2007.02167.X

[7] da Silva Sabo, S., Converti, A., Todorov, S.D., Domínguez, J.M., De Souza OLIVEIRA, R.P. (2015): Effect of inulin on growth and bacteriocin production by Lactobacillus plantarum in stationary and shaken cultures. International Journal of Food Science and Technology 50 (4): 864-870. doi: 10.1111/ijfs.12711

[8] Grujović, M.Ž., Mladenović, K.G, Žugić Petrović, T.D., Čomić, L.R. (2019a): Assessment of the antagonistic potential and ability of biofilm formation of Enterococcus spp. isolated from Serbian cheese. Veterinarski arhiv 89 (5): 653-667. doi: 10.24099/vet.arhiv.0485

[9] Grujović, M.Ž., MLadenović, K.G, NikodiJević D.D., Čomić, L.R. (2019b): Autochthonous lactic acid bacteria - presentation of potential probiotics application. Biotechnology Letters 41: 1319-1331. doi: 10.1007/s10529-019-02729-8

[10] Gustaw, W., Kordowska-Wiater, M., KoziOł, J. (2011): The influence of selected prebiotics on the growth of lactic acid bacteria for bio-yoghurt production. Acta Scientiarum Polonorum Technologia Alimentaria 10 (4): 455-466. 
[11] Hernandez-Hernandez, O.A., Muthaiyan, F.J., Moreno, A., Montilla, M.L., SANZ, S., RICKEET, C. (2012): Effect of prebiotic carbohydrates on the growth and tolerance of Lactobacillus. Food Microbiology 30 (2): 355-361.

doi: 10.1016/j.fm.2011.12.022

[12] KaPlan, H., HutKins, R. (2000): Fermentation of fructooligosaccharides by lactic acid bacteria and bifidobacteria. Applied and Environmental Microbiology 66 (6): 2682. doi: 10.1128/aem.66.6.2682-2684.2000

[13] Kimoto-Nira, H., Mizumachi, K., Nomura, M., Kobayashi, M., Fujita, Y., Oкамото, T., Suzuki, I., Tsuji, N.M., Kurisaki, J., Oнмомо, S. (2007): Lactococcus sp. as potential probiotic lactic acid bacteria. Japan Agricultural Research Quarterly 41 (3): 181-189. doi: 10.6090/jarq.41.181

[14] Magdoub, M.N.I., Hassan, Z.M R., EfFat, B.A.M., SAdeK, Z.I.M., TAwFiK, N.F., MABRouK, A.M.M. (2015): Probiotic properties of some lactic acid bacteria isolated from Egyptian dairy products. International Journal of Current Microbiology and Applied Science 4 (12): 758-766.

[15] Muruzović, M.Ž., Mladenović, K.G., ŽugiĆ-Petrović T.D, ČOMić, L.R. (2018a). Characterization of lactic acid bacteria isolated from traditionally made Serbian cheese and evaluation of their antagonistic potential against Enterobacteriaceae. Journal of Food Processing and Preservation 42 (4): e13557. doi: 10.1111/jfpp.13577

[16] Muruzović, M.Ž., Mladenović, K.G., DJilas, M.D, Stefanović, O.D., Čomić, L.R. (2018b): In vitro evaluation of antimicrobial potential and ability of biofilm formation of autochthonous Lactobacillus spp. and Lactococcus spp. isolated from traditionally made cheese from Southeastern Serbia. Journal of Food Processing and Preservation 42 (11): e13776. doi: 10.1111/jfpp.13776

[17] Okuro, P.K., Thomazini, M., Balieiro, J.C.C., Liberal, R.D.C.O., FávaroTRINDADE, C.S. (2013): Co-encapsulation of Lactobacillus acidophilus with inulin or polydextrose in solid lipid microparticles provides protection and improves stability. Food Research International 53 (1): 96-103.

doi: 10.1016/j.foodres.2013.03.042

[18] Pavli, P.G., Argyri, A.A., Papadopoulou, O.S., Nychas, G.E., Chorianopoulos, N.G., TASSOU C.C. (2016): Probiotic potential of lactic acid bacteria from traditional fermented dairy and meat products: assessment by in vitro tests and molecular characterization. Journal of Probiotics and Health 4 (3): 157-165. doi: 10.4172/2329-8901.1000157

[19] Pranckutė, R., Kaunietis, A., Kuisienė, N., ČitaviČIUs, D. (2014): Development of synbiotics with inulin, palatinose, $\alpha$-cyclodextrin and probiotic bacteria. Polish Journal of Microbiology 63 (1): 33-41. doi: 10.33073/pjm-2014-005

[20] Rada, V., Nevoral, J., TrojanovÁ, I., TománkovÁ, E., ŠMehilová, M., Killer J. (2008): Growth of infant faecal bifidobacteria and clostridia on prebiotic oligosaccharides in in vitro conditions. Anaerobe 14 (4): 205-208. doi: 10.1016/j.anaerobe.2008.05.003

[21] Romano, N., Tymczyszyn, E., Mobili, P., Gomez-Zavaglia, A. (2016): Prebiotics as protectants of lactic acid bacteria. In: WATSON, R. R., PREEDY, V. R (ed.) Bioactive foods in promoting health: probiotics, prebiotics, and synbiotics, $2^{\text {nd }}$ Edition. Elsevier Inc. doi: 10.1016/B978-0-12-802189-7.00010-1 
[22] Ross, R.P., Desmond, C., Fitzgerald, G.F., Stanton, C. (2005): Overcoming the technological hurdles in the development of probiotic foods. Journal of Applied Microbiology 98 (6): 1410-1417. doi: 10.1111/j.1365-2672.2005.02654.x

[22] SAHA, B.C., RACINE, F.M. (2011): Biotechnological production of mannitol and its applications. Applied Microbiology and Biotechnology 89: 879-891. doi: 10.1007/s00253-010-2979-3

[23] Sarangi, N.R., Babu, L.K., Kumar, A., Pradhan, C.R., Pati, P.K., Mishra J.P. (2016): Effect of dietary supplementation of prebiotic, probiotic, and synbiotic on growth performance and carcass characteristics of broiler chickens. Veterinary World 9 (3): 313-319. doi: 10.14202/vetworld.2016.313-319

[24] SchrezenmeIR, J., DE VRese, M. (2001): Probiotics, prebiotics and synbiotics approaching a definition. The American Journal of Clinical Nutrition 73 (2): 361s364s. doi: 10.1093/ajen/73.2.361s

[25] Shokryazdan, P., Sieo, C.C., Kalavathy, R., Liang, J.B., Alithee, N.B., JahroMI, M.F., Ho, Y.W. (2014): Probiotic potential of Lactobacillus strains with antimicrobial activity against some human pathogenic strains. BioMed Research International 2014: 1-16. doi: 10.1155/2014/927268

[26] TAmime, A.Y., Robinson, R.K. (1999): Yoghurt: Science and Technology, $2^{\text {nd }}$ ed. Cambridge: Woodhead Publishing Ltd. 23 pp.

[27] Uroić, K., Nikolić, M., Koslć, B., Pavunc, L., Beganović, J., Lukić, J., JovČić, B., Filipić, B., Miljković, M., Golić, N., Topisirović, LJ., ČAdEž, N., RAsPor, P., ŠUŠKOVIĆ, J. (2014): Probiotic properties of lactic acid bacteria isolated from Croatian fresh soft cheese and Serbian white pickled cheese. Food Technology and Biotechnology 52 (2): 232-241. 